Terbit online pada laman web jurnal : http://teknosi.fti.unand.ac.id/

Jurnal Nasional Teknologi dan Sistem Informasi

ISSN (Print) 2460-3465 | ISSN (Online) 2476-8812

Studi Kasus

\title{
Perancangan Maintenance Management Information System untuk Unit Pemadam Kebakaran (Studi Kasus : Perusahaan X)
}

\author{
Arief Samuel Gunawan ${ }^{1}$, Ari Setiawan ${ }^{1}$, Febryci Legirian ${ }^{1}$ \\ ${ }^{1}$ Institut Teknologi Harapan Bangsa, Jl.Dipati Ukur 80-84, Bandung 40132, Indonesia
}

\begin{tabular}{|c|}
\hline INFORMASI ARTIKEL \\
\hline $\begin{array}{l}\text { Sejarah Artikel: } \\
\text { Diterima Redaksi: } 02 \text { Desember } 16 \\
\text { Revisi Akhir: } 02 \text { Juni } 16 \\
\text { Diterbitkan Online: } 31 \text { Agustus } 17\end{array}$ \\
\hline KATA KUNCI \\
\hline $\begin{array}{l}\text { Maintenance Management Information System } \\
\text { (MMIS) }\end{array}$ \\
\hline Total Productive Maintenance (TPM) \\
\hline Reliability Centered Maintenance (RCM) \\
\hline KORESPONDENSI \\
\hline Telepon: +628122385990 \\
\hline E-mail: arief@ithb.ac.id \\
\hline
\end{tabular}

\section{A B S T R A C T}

Fire Department is a division of Company $X$ whose task is to prevent and put out fires in the company area. The firefighters are equipped with tools and equipments to support their job, one particular important equipment is the fire truck. The problem is that fire trucks often have breakdowns while in operation. This problem mainly occurs because the components of fire trucks run out of lifetime and has not been replaced with new spareparts. Maintenance technicians often don't have adequate information about component lifetime for every fire trucks. As a result the firefighters could not anticipate whether breakdowns would occur. To solve this problem, a Maintenance Management Information System (MMIS) is developed to help forecasting each component's lifetimes. Reliability Centered Maintenance method (RCM) is applied in MMIS to determine Mean Time To Failure (MTTF), as well as Total Productive Maintenance method (TPM) to help with the maintenance schedules. Thus the firefighters can get information about fire truck components lifetime and breakdowns of fire trucks can be minimized. A configuration menu is provided to support MMIS in the areas of employee data, fire truck inventories, sparepart inventory and procurement feature that is related with maintenance cost.

\section{PENDAHULUAN}

Kebakaran merupakan suatu peristiwa atau kejadian timbulnya api yang tidak terkendali yang dapat membahayakan keselamatan jiwa maupun harta benda. Mobil pemadam kebakaran berperan sangat penting dalam proses penanggulangan kebakaran, sehingga kondisi kendaraan tersebut harus berada dalam kondisi yang siap pakai ketika terjadi kebakaran. Unit Pemadam Kebakaran Perusahaan X bertugas untuk menelola pemeliharaan seluruh mobil pemadam kebakaran. Kegiatan pemeliharaan dilakukan secara rutin pada setiap mobil pemadam kebakaran untuk menjaga kondisi kendaraan dengan melakukan pengecekan setiap hari kerja. Apabila dari hasil pengecekan terdapat gejala kerusakan, kegiatan perbaikan akan dipertimbangkan oleh pihak Teknisi, sedangkan penggantian oli dilakukan secara rutin berdasarkan waktu atau jarak tempuh tertentu yang telah ditentukan, namun beberapa kali terjadi kerusakan pada mobil pemadam kebakaran saat digunakan, kerusakan yang dialami sangat beragam, mulai dari komponen lampu mobil yang mati,

https://doi.org/10.25077/TEKNOSI.v3i2.2017.219-224 hingga kerusakan master kopling. Sekecil apapun kerusakan yang terjadi pada mobil pemadam kebakaran memungkinkan terhambatnya proses penanggulangan kebakaran.

Pada hakikatnya setiap aset peralatan pasti memiliki umur pakai, tetapi usia kegunaannya dapat diperpanjang dengan melakukan perbaikan berkala dengan suatu aktifitas yang dikenal sebagai maintenance atau pemeliharaan [1]. Mobil pemadam kebakaran biasanya digunakan hingga kapasitas maksimal, akibatnya dapat menyebabkan komponen mobil rentan mengalami kerusakan saat digunakan. Namun, kerusakan tersebut dapat dicegah apabila bagian pemeliharaan memiliki informasi umur komponen mobil pemadam kebakaran hingga komponen rusak, sehingga pemeliharaan kendaraan dapat dijadwalkan sebelum terjadi kerusakan pada mobil pemadam kebakaran. Untuk meningkatkan kualitas manajemen pemeliharaan mobil pemadam kebakaran, maka peran teknologi informasi dapat dimanfaatkan dengan merancang sistem informasi manajemen pemeliharaan yang dapat mengolah data secara otomatis untuk memberikan informasi yang diperlukan dalam kegiatan manajemen pemeliharaan untuk meminimalisir terjadinya kerusakan saat

Attribution-NonCommercial 4.0 International. Some rights reserved 
mobil digunakan sehingga dapat menunjang kegiatan penanggulangan kebakaran.

\section{TINJAUAN PUSTAKA}

Maintenance Management (Manajemen Perawatan atau Pemeliharaan)

Maintenance management atau manajemen pemeliharaan adalah pengelolaan pekerjaan pemeliharaan dengan melalui suatu proses perencanaan, pengorganisasian serta pengendalian operasi pemeliharaan untuk memberikan performasi mengenai fasilitas industry. Tujuan utama dari pemeliharaan yaitu [1]:

1. Untuk memperpanjang usia.

2. Untuk menjamin ketersediaan optimum.

3. Untuk menjamin kesiapan operasional.

4. Untuk menjamin keselamatan orang yang menggunakan sarana.

Berdasarkan definisi Mgruppen Partner dalam buku yang berjudul Industrial Maintenance Management menyebutkan bahwa pemeliharaan dapat dibedakan menjadi tiga bagian besar yaitu, corrective maintenance, preventive maintenance dan improvement maintenance [2].

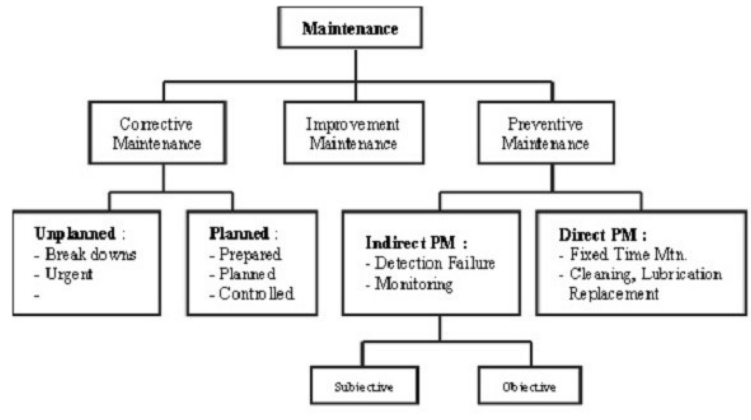

Gambar 1 Karakteristik Pemeliharaan Berdasarkan Definisi Mgruppen

\section{Preventive Maintenance}

Preventive maintenance (PM) meliputi semua pemeliharaan terprogram yang dilakukan untuk mencegah terjadinya failure atau untuk mendeteksi failure sebelum kegagalan tersebut menjadi kerusakan atau mengganggu kegiatan produksi. Sasaran dari PM yaitu mencegah terjadinya kerusakan, mendeteksi kerusakan yang akan terjadi, serta menemukan kerusakan yang tersembunyi[6].

\section{Corrective Maintenance}

Corrective maintenance (CM) mencakup semua kegiatan pemeliharaan yang dilakukan dalam rangka untuk memperbaiki kesalahan yang terdapat pada peralatan [2]. Dalam kata lain dapat diartikan bahwa CM merupakan kegiatan pemeliharaan yang bertujuan untuk memperbaiki suatu kondisi dari tidak atau kurang baik menjadi lebih baik. CM dapat dibedakan menjadi dua, yaitu Planned CM; dilakukan apabila telah diketaui sejak dini kapan peralatan yang harus diperbaiki, dan unplanned CM; dilakukan apabila mesin/peralatan telah benar-benar mati.

\section{Improvement Maintenance}

Improvement maintenance yaitu memodifikasi beberapa komponen dari suatu peralatan yang bertujuan untuk memperpanjang umur komponen, meningkatkan nilai teknologi serta menghindari komponen yang sudah obsolete [2].

\section{Total Productive Maintenance (TPM)}

Total Productive Maintenance (TPM) merupakan suatu pendekatan yang digunakan untuk memaksimalkan efektivitas dari suatu peralatan/fasilitas yang digunakan di perusahaan dengan melibatkan seluruh karyawan perusahaan[4].. Konsep dari TPM yaitu menggerakan semua karyawan dalam suatu kelompok untuk melakukan improvement pada suatu peralatan.

\section{Reliability Centered Maintenance (RMC)}

Reliability sangat berhubungan erat dengan kerusakan suatu peralatan serta umur (individual live time) dari komponen. Umur komponen tersebut dipengaruhi oleh kualitas dari produk (komponen/parts) serta faktor lain seperti cara pengoperasian, metode perawatan, lingkungan dan lain-lain. Reliability sering juga disebut dengan kerusakan atau failure [3].Reliability performance adalah waktu rata-rata dari suatu alat yang sanggup untuk beroperasi diantara dua kejadian berhenti karena kegiatan pemeliharaan, reliability performance dapat diukur dengan Mean Time To Failure (MTTF) [5]. Untuk mengukur reliability performance, perlu mendefinisikan kerusakan dengan jelas dan satuan yang digunakan dalam suatu kurun waktu yang jelas (jam operasional, jumlah pendaratan dan jumlah siklus lain).Mean Time to Failure (MTTF) atau rata - rata waktu sebelum terjadi kerusakan dari nilai tersebut dengan menggunakan formula

$$
M T T F=\frac{\sum T T F}{\text { Jumlah kerusakan }}(1)
$$

\section{Maintenance management information system (MMIS)}

Merupakan sistem informasi yang dirancang untuk membantu dalam memanajemen kegiatan pemeliharaan sehingga dapat membantu dalam memberikan informasi penting dalam kegiatan pemeliharaan, serta dapat meningkatkan kualitas pemeliharaan. MMIS merupakan penerapan teknologi informasi didalam sebuah organisasi pemeliharaan. Manajemen pemeliharaan berbasis komputer dapat membantu perusahaan dengan pengumpulan data yang lebih baik, penyusunan laporan yang lebih akurat untuk pengambilan keputusan, pengurangan down time, pengurangan biaya maintenance, peningkatan produktivitas, pengurangan biaya inventori serta berkurangnya penggunaan kertas [8].

\section{ANALISIS MASALAH DAN PENGOLAHAN DATA}

Proses identifikasi masalah dalam perancangan system informasi manajemen pemeliharaan mobil pemadam kebakaran ini, dilihat dari kegiatan pemeliharaan mobil pemadam kebakaran yang saat ini dilakukan di Unit Pemadam Kebakaran Perusahaan X. Analisis masalah awal menggunakan cause and effect diagram (fishbone diagram) seperti dapat dilihat di gambar 2 .

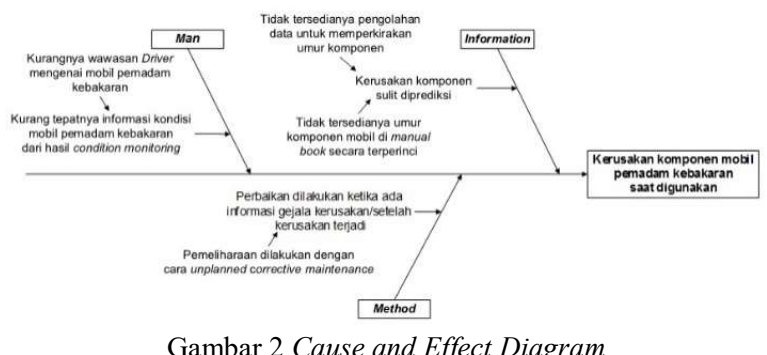

Gambar 2 Cause and Effect Diagram 
Dari diagram tersebut dapat dilihat beberapa faktor yang menyebabkan mobil pemadam kebakaran mengalami kerusakan pada komponen teretentu saat digunakan, terdapat 3 aspek penyebab masalah. Berikut penjelasan dari aspek-aspek tersebut:

\section{Information}

Permasalahan dari aspek informasi yaitu karena kerusakan komponen kendaraan yang sulit di prediksi dikarenakan tidak tersedianya data umur komponen mobil pemadam kebakaran. Hal tersebut terjadi karena komponen mobil pemadam kebakaran memiliki komponen yang sangat banyak dan hanya beberapa komponen yang memiliki informasi umur komponen yang terdapat di dalam manual book yang telah diberikan pabrikan mobil tersebut.

\section{Method}

Penyebab masalah yang kedua terdapat pada aspek method, dimana pemeliharaan dilakukan setelah terdeteksi gejala kerusakan atau setelah kendaraan rusak. Kegiatan tersebut terjadi karena setiap kegiatan perbaikan dilakukan ketika ada laporan kerusakan atau kendala dari bagian Operasional.

\section{Man}

Aspek man terjadi karena kurang tepatnya informasi mengenai kondisi kendaraan yang diberikan, hal tersebut disebabkan karena pengemudi yang melakukan pengecekan kondisi kendaraan kurang memahami karakter kendaraan tesebut dikarenakan kurangnya wawasan mengenai mobil pemadam kebakaran.

Dari permasalahan yang ada, dapat ditentukan gap antara proses pemeliharaan yang saat ini berjalan dengan proses pemeliharaan yang diinginkan, dapat ditentukan beberapa kebutuhan yang diperlukan untuk mencapai tujuan tersebut. Kebutuhan tersebut yaitu:

1. Memprediksi umur komponen mobil pemadam kebakaran untuk mendapatkan informasi perkiraan umur komponen mobil pemadam kebakaran berdasarkan histori data kerusakan.

2. Menyediakan penjadwalan untuk pemeliharaan berdasarkan informasi perkiraan umur komponen kendaraan untuk mencegah terjadinya kerusakan komponen saat mobil pemadam kebakaran beroperasional.

Berdasarkan kebutuhan yang dilihat pada gap analisis, maka diperlukan beberapa metode untuk mencapai kebutuhan dengan mengolah data-data yang telah ditentukan. Dalam penelitian ini terdapat dua metode yang dapat digunakan yaitu metode Reliabillity Centered Maintenance (RCM) dan Total Productive Maintenance (TPM). Berikut merupakan penjelasan penggunaan kedua metode di dalam sistem yang akan diusulkan:

\section{Metode RCM}

Untuk menentukan umur komponen pada mobil pemadam kebakaran, dilakukan pengolahan pada data histori kegiatan pemeliharaan yang telah dilakukan, dari data tersebut diambil informasi kerusakan yang terjadi pada komponen mobil pemadam kebakaran berdasarkan satuan waktu. Dari data kerusakan komponen tersebut dapat ditentukan nilai MTTF suatu kerusakan pada komponen mobil pemadam kebakran menggunakan metode RCM.

\section{Metode TPM}

Metode TPM digunakan untuk menentukan jadwal pemeliharaan mobil pemadam kabakaran berdasarkan umur komponen mobil pemadam kebakaran. Dari 7 pilar yang ada di dalam metode TPM, ditentukan bahwa hanya 3 pilar yang akan

https://doi.org/10.25077/TEKNOSI.v3i2.2017.219-224 diterapkan, ketiga pilar tersebut diterapkan karena sangat berkaitan dengan jadwal pemeliharaan mobil pemadam kebakaran. Ketiga pilar tersebut yaitu:

\section{a. Autonomous Maintenance (AM)}

Pilar AM digunakan untuk melakukan kegiatan pengecekan rutin yang dapat dilakukan oleh Driver setiap mobil pemadam kebakaran untuk memastikan bahwa kondisi mobil pemadam kebakaran setiap hari kerja.

\section{b. Planned Maintenance (PM)}

Pilar PM diterapkan untuk menentukan jadwal pemeliharaan/fixed maintenance yang berkaitan dengan perkiraan umur komponen mobil pemadam kebakaran yang ditentukan dengan menggunakan metode RCM. Dengan menerapkan pilar ini, maka kegiatan pemeliharaan dapat dilakukan tanpa menunggu keluhan dari Driver atau menunggu mobil mengalami kerusakan terlebih dahulu, sehingga meminimalisir terjadinya kerusakan saat mobil pemadam kebakaran digunakan.

\section{c. Quality maintenance $(\mathrm{QM})$}

Pilar QM diterapkan untuk memastikan kualitas dari setiap mobil pemadam kebakaran sehingga dapat memberikan informasi kondisi kendaraan secara keseluruhan.

Berikut merupakan keterkaitan antara fungsi tujuan yang ingin dicapai dengan metode yang akan digunakan yang dijelaskan pada gambar 3 .

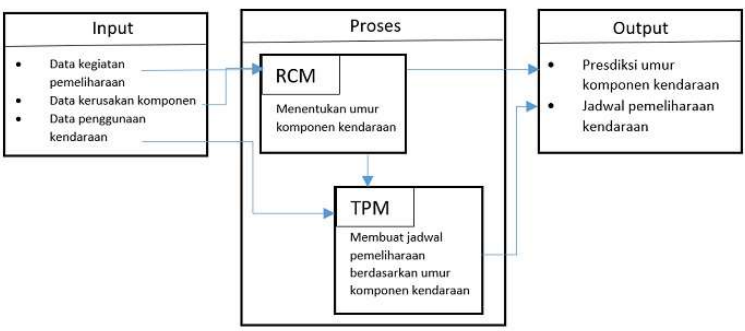

Gambar 3 Penerapan Metode RCM dan TPM

Berikut adalah contoh dari pengolahan data yang dilakukan sesuai dengan tahap-tahap diatas. Dari total mobil yang ada,diambil 3 sampel mobil dengan beberapa kejadian kerusakan terhadap mobil tersebut seperti dapat dilihat di tabel 1 .

Tabel 1. Sampel Data Kerusakan Mobil Pemadam Kebakaran dalam 1 Tahun

\begin{tabular}{|c|c|c|c|c|c|c|}
\hline $\begin{array}{l}\text { No. } \\
\text { Unit }\end{array}$ & Tanggal & $\begin{array}{l}\text { Jam Opr. } \\
\text { Awal }\end{array}$ & $\begin{array}{l}\text { Jam Opr. } \\
\text { Akhir }\end{array}$ & $T T F$ & Kerusakan & Ket. \\
\hline 117 & $28 / 03 / 2014$ & $0 \mathrm{Jam}$ & $200 \mathrm{Jam}$ & $200 \mathrm{Jam}$ & Rem boster pusat & Keausan \\
\hline 113 & $04 / 04 / 2014$ & $0 \mathrm{Jam}$ & $216 \mathrm{Jam}$ & $216 \mathrm{Jam}$ & Rem boster pusat & Keausan \\
\hline 118 & $12 / 04 / 2014$ & $600 \mathrm{Jam}$ & $1033 \mathrm{Jam}$ & $433 \mathrm{Jam}$ & Sistem rem tangan & Perlu diset \\
\hline 113 & $01 / 05 / 2014$ & $0 \mathrm{Jam}$ & $275 \mathrm{Jam}$ & $275 \mathrm{Jam}$ & Sistem coupling & Rusak \\
\hline 117 & $01 / 05 / 2014$ & $0 \mathrm{Jam}$ & $300 \mathrm{Jam}$ & $300 \mathrm{Jam}$ & Sistem coupling & Rusak \\
\hline 113 & $12 / 10 / 2014$ & $216 \mathrm{Jam}$ & $466 \mathrm{Jam}$ & $250 \mathrm{Jam}$ & Rem boster pusat & Keausan \\
\hline 117 & $18 / 10 / 2014$ & $200 \mathrm{Jam}$ & $458 \mathrm{Jam}$ & $258 \mathrm{Jam}$ & Rem boster pusat & Keausan \\
\hline 113 & $24 / 12 / 2014$ & $275 \mathrm{Jam}$ & $536 \mathrm{Jam}$ & $261 \mathrm{Jam}$ & Sistem coupling & Rusak \\
\hline 117 & $28 / 12 / 2014$ & $300 \mathrm{Jam}$ & $583 \mathrm{Jam}$ & $283 \mathrm{Jam}$ & Sistem coupling & Rusak \\
\hline 118 & $28 / 12 / 2014$ & $1033 \mathrm{Jam}$ & $1491 \mathrm{Jam}$ & $458 \mathrm{Jam}$ & Sistem rem tangan & Perlu diset \\
\hline
\end{tabular}

Keterangan : TTF (Time to failure) adalah jumlah jam sampai kerusakan berikutnya.

Untuk setiap unit mobil dilakukan rekapitulasi perhitungan seperti pada tabel 2 dibawah ini, dengan contoh unit 113 .

Tabel 2. Data Kerusakan Unit 113 


\begin{tabular}{|c|c|c|c|c|c|}
\hline $\begin{array}{c}\text { No. } \\
\text { Unit }\end{array}$ & Tanggal & $\begin{array}{c}\text { Jam Opr. } \\
\text { Awal }\end{array}$ & $\begin{array}{c}\text { Jam Opr. } \\
\text { Akhir }\end{array}$ & TTF & Kerusakan \\
\hline $\mathbf{1 1 3}$ & $04 / 04 / 2014$ & $0 \mathrm{Jam}$ & $216 \mathrm{Jam}$ & $216 \mathrm{Jam}$ & Rem boster pusat \\
\hline $\mathbf{1 1 3}$ & $01 / 05 / 2014$ & 0 Jam & $275 \mathrm{Jam}$ & $275 \mathrm{Jam}$ & Sistem coupling \\
\hline $\mathbf{1 1 3}$ & $12 / 10 / 2014$ & $216 \mathrm{Jam}$ & $466 \mathrm{Jam}$ & $250 \mathrm{Jam}$ & Rem boster pusat \\
\hline $\mathbf{1 1 3}$ & $24 / 12 / 2014$ & $275 \mathrm{Jam}$ & $536 \mathrm{Jam}$ & $261 \mathrm{Jam}$ & Sistem coupling \\
\hline
\end{tabular}

Pada tabel tersebut dapat dilihat bahwa kerusakan mobil pemadam kebakaran terjadi sebanyak empat kali, yaitu pada rem boster pusat yang mengalami keasuan setelah digunakan selama 216 jam dan 250 jam. Selain itu sistem coupling juga mengalami kerusakan setelah digunakan selama 275 jam dan 261 jam. Dari data di atas, kerusakan pada komponen/part yang sama dapat diprediksi dengan mencari Mean Time to Failure (MTTF) atau rata - rata waktu sebelum terjadi kerusakan dari nilai tersebut .

Tabel 3. Nilai Perhitungan Mean Time To Failure Unit 113

\begin{tabular}{|l|l|l|l|l|}
\hline No & $\begin{array}{c}\text { Nomor } \\
\text { Unit }\end{array}$ & \multicolumn{1}{|c|}{ Kerusakan } & \multicolumn{1}{|c|}{ TTF } & \multicolumn{1}{c|}{$\begin{array}{c}\text { Jumlah } \\
\text { kerusakan }\end{array}$} \\
\hline $\mathbf{1}$ & 113 & Rem boster pusat & 216 Jam & 1 \\
\hline $\mathbf{2}$ & 113 & Rem boster pusat & 250 Jam & 2 \\
\hline & & MTTF & \multicolumn{2}{|c|}{$\frac{(216+250)}{2}=233 \mathrm{Jam}$} \\
\hline $\mathbf{3}$ & 113 & Sistem coupling & 275 Jam & 1 \\
\hline $\mathbf{4}$ & 113 & Sistem copuling & 261 Jam & 2 \\
\hline & & MTTF & \multicolumn{2}{|c|}{$\frac{(275+261)}{2}=268 \mathrm{Jam}$} \\
\hline
\end{tabular}

Pada rekapitulasi dari tabel 3 didapat MTTF dari part rem boster pusat yaitu 233 jam dan nilai MTTF dari sistem coupling yaitu 268 jam. Kedua nilai MTTF tersebut dapat dijadikan sebagai perkiraan kerusakan selanjutnya dimana part dari rem boster pusat harus diganti saat mobil unit 113 mencapai waktu operasional 233 jam dan sistem coupling harus diganti saat mobil beroperasional selama 268 jam.

Dari nilai-nilai MTTF yang didapatkan berdasarkan perhitungan yang telah dilakukan, maka dapat membantu Unit Pemadam Kebakaran dalam melakukan perhitungan perkiraan umur komponen/part pada setiap unit mobil pemadam kebakaran sehingga nilai tersebut dapat dijadikan patokan untuk membuat jadwal pemeliharaan mobil pemadam kebakaran dan membantu dalam menentukan deskripsi pekerjaan dalam kegiatan pemeliharaan. Selain itu, keperluan sparepart dan peralatan untuk pemeliharaan juga dapat dipersiapkan, sehingga kegiatan pemeliharaan dapat dilakukan lebih cepat dengan mengurangi waktu down time, sehingga nilai availability dari seluruh unit mobil pemadam kebakaran dapat ditingkatkan. Model perhitungan ini akan dimasukkan ke dalam system informasi yang akan dirancang sehingga untuk setiap unit mobil pemadam kebakaran dan setiap komponennya terdapat perhitungan yang lengkap tentang umur komponen dan estimasi waktu perbaikan dan pergantian.

\section{PERANCANGAN DAN IMPLEMENTASI SISTEM INFORMASI}

Sistem informasi manajemen pemeliharaan mobil pemadam kebakaran diusulkan untuk dijadikan sebagai solusi yang tepat untuk mengatasi masalah yang ada di Perusahaan X dengan mengolah histori data kerusakan komponen dan kegiatan pemeliharaan yang telah dilakukan sehingga menghasilkan informasi perkiraan umur dari komponen mobil pemadam kebakaran, pengolahan data tersebut dapat memerlukan beberapa input data yang diperlukan oleh sistem sehingga sistem dapat mengolah data tersebut menjadi output data yang merupakan informasi perkiraan umur komponen mobil pemadam kebakaran serta, informasi penting lain yang berkaitan dengan pemeliharaan untuk memudahkan bagian pemeliharaan dalam membuat laporan dan melakukan evaluasi.

Dalam perancangan sistem informasi manajemen pemeliharaan mobil pemadam kebakaran ini dibuat dengan beberapa tahapan perancangan. Tahapan terdiri dari DFD, ERD, hingga User Interface. Pada DFD, dibagi beberapa level dimulai dari context diagram hingga pembagian DFD ke dalam beberapa level.Gambar 4 menunjukkan rancangan context diagram untuk Maintenance Managemant Information System (MMIS) Mobil Pemadam Kebakaran. Context diagram tersebut menggambarkan alur data secara menyeluruh antara user atau setiap divisi dengan sistem yang akan dibuat.Untuk menggambarkan relasi data, dibuatlah skema relasi dalam Entity Relationship Diagram (ERD) yang ditunjukkan oleh gambar 5 .

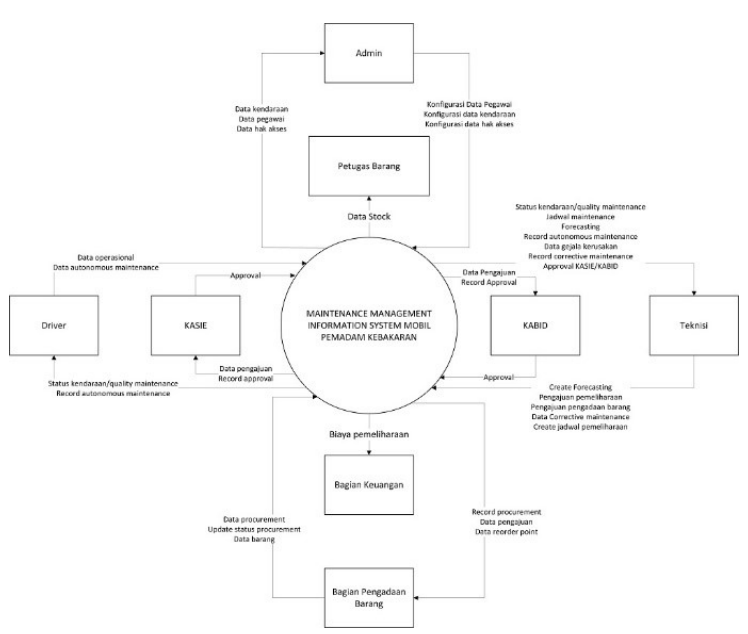

Gambar 4. Context Diagram (DFD Level 0)

Hasil implementasi dari perancangan sistem yang dikembangkan, dibuat dalam bahasa pemrograman PHP dan menggunakan database MYSQL. Berikut ini merupakan beberapa hasil dari user interface di dalam Maintenance Management Information Ststem (MMIS) Untuk Unit Pemadam Kebakaran yang dibuat seperti terlihat di Gambar 6.

Fitur-fitur utama dari system antara lain pengelolaan master data unit mobil pemadam kebakaran, pencatatan corrective maintenance (perbaikan), penjadwalan dan pencatatan preventive maintenance (service berkala), forecasting preventive maintenance dan pencatatan pengajuan pengadaan komponen. Gambar 7 menunjukkan salah satu contoh interface sistem untuk fitur Corrective Maintenance. Pada interface corrective maintenance user dapat mencatat semua kegiatan pemeliharaan yang dilakukan pada setiap mobil pemadam kebakaran dengan mengisi form data corrective maintenance yang terdapat pada halaman kerja sistem. Data kerusakan yang masukan, akan menjadi data histori acuan untuk melakukan forecasting kerusakan.

Gambar 8 menunjukkan fitur Preventive Maintenance untuk forecasting Kerusakan, dimana user dapat melakukan perhitungan untuk memprediksi kerusakan komponen mobil pemadam kebakaran dengan mengisi form forecasting 
kerusakan yang terdapat pada baris kedua pada halaman kerja sistem.

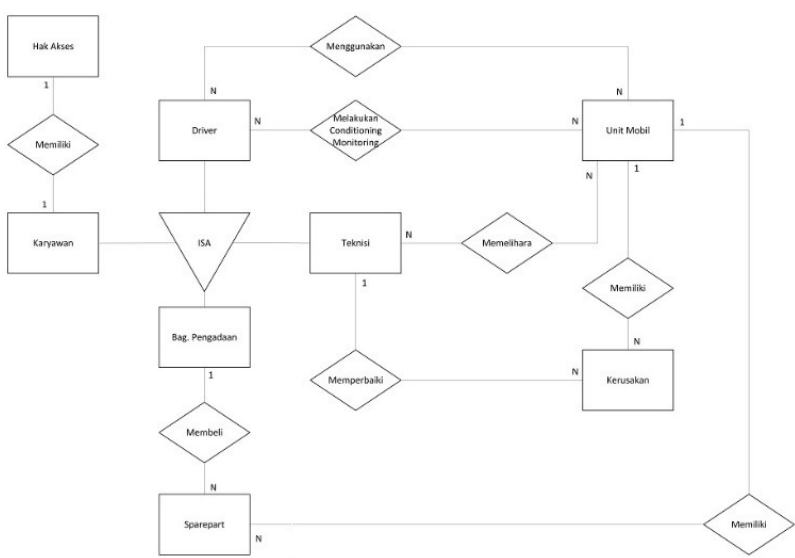

Gambar 5. Entity Relationship Diagram (ERD)

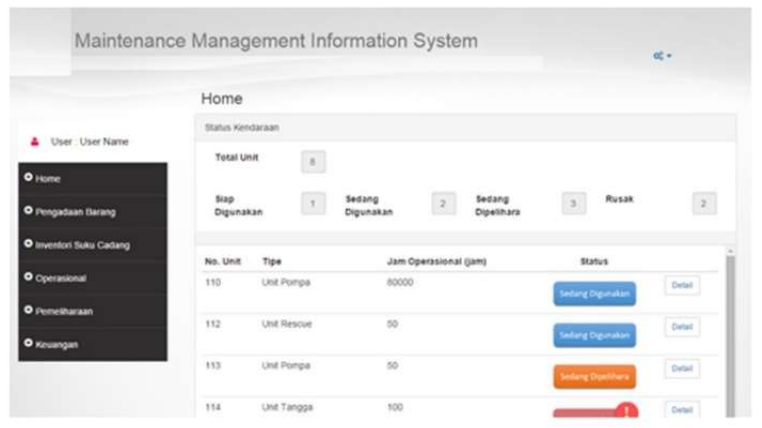

Gambar 6 Interface Halaman Utama Maintenance Management Information System

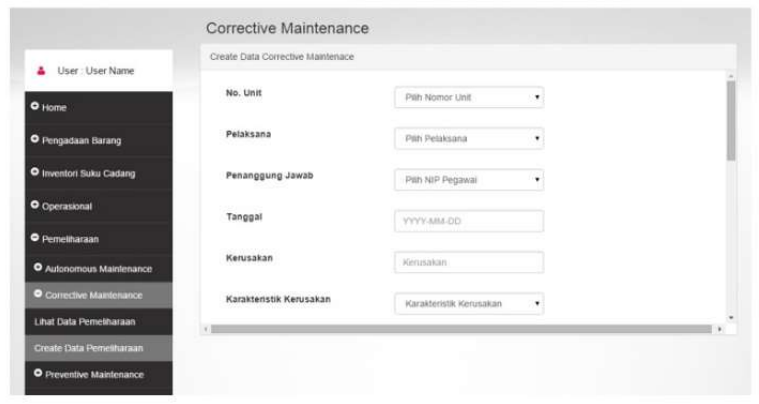

Gambar 7 Interface Corrective Maintenance

Pada interface jadwal maintenance, user dapat melihat data pemeliharaan terencana yang telah dijadwalkan berdasarkan perhitungan nilai Mean Time To Failure (MTTF) dan juga jadwal yang dibuat secara manual tanpa perhitungan nilai MTTF. Selain itu rekapitulasi perbaikan dan penggunaan sparepart juga menghasilkan informasi tentang biaya yang digunakan untuk setiap kegiatan perbaikan maupun pemeliharaan berkala.

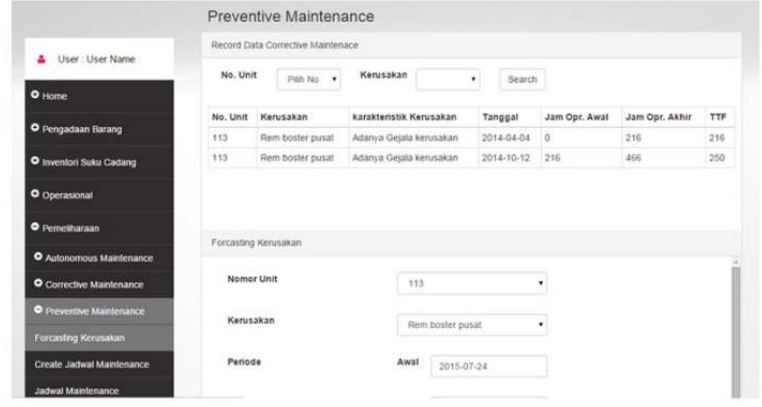

Gambar 8. Interface Preventive Maintenance

\section{KESIMPULAN}

1. Fitur perhitungan forecasting kerusakan komponen kendaraan menggunakan metode Reliability Centered Maintenance (RCM) pada sistem informasi manajemen pemeliharaan mobil pemadam kebakaran dapat memberikan informasi umur komponen kendaraan secara dinamis setiap waktu asalkan pencatatannya konsisten.

2. Hasil penerapan metode Total Productive Maintenance (TPM) pada menu pemeliharaan pada sistem yang telah dikembangkan, menghasilkan fitur Autonomous Maintenance (AM) yang dapat mengoptimalkan kegiatan pemeliharaan dengan melakukan condition monitoring pada setiap mobil, Preventive Maintenance (PM) yang digunakan untuk membuat jadwal pemeliharaan secara otomatis, dan Quality Maintenance (QM) yang dapat memberikan informasi kondisi mobil pemadam kebakaran secara keseluruhan.

3. Dengan adanya informasi umur komponen pada setiap mobil, maka kebutuhan komponen atau sparepart dapat diprediksi, sehingga bagian Pengadaan Barang dapat mengetahui informasi kebutuhan sparepart untuk kegiatan pemeliharaan yang telah direncanakan dan Bagian pengadaan barang dapat mempersiapkan sparepart yang dibutuhkan untuk mendukung kegiatan pemeliharaan.

4. Dengan adanya sistem informasi manajemen pemeliharaan mobil pemadam kebakaran, dapat mempermudah dan mempercepat proses komunikasi antara bagian dan personil terkait.

5. Sistem informasi manajemen pemeliharaan mobil pemadam kebakaran dapat memberikan informasi biaya pemeliharaan yang telah dilakukan selama periode waktu tertentu yang dapat disesuaikan sesuai dengan kebutuhan.

Berdasarkan penelitian yang telah dilakukan dan sistem informasi manajemen pemeliharaan yang telah dikembangkan, maka terdapat beberapa saran untuk pengembangan lebih lanjut dari penelitian ini. Berikut merupakan saran untuk pengembangan penelitian lebih lanjut:

1. Menyediakan fitur untuk pengelolaan data supplier suku cadang dan pengelolaan data bengkel rekan.

2. Menambahkan fitur untuk melakukan perhitungan down time yang didapatkan dari hasil waiting time dan time to repair. 


\section{UCAPAN TERIMA KASIH}

Terima kasih disampaikan kepada Perusahaan $\mathrm{X}$ yang telah bersedia memfasilitasi penelitian ini, kepada pihak Institut Teknologi Harapan Bangsa atas segala dukungan yang diberikan, serta kepada segenap dosen dan anggota tim yang terlibat.

\section{DAFTAR PUSTAKA}

[1] Corder, Antony. 1992. Teknik Manajemen Pemeliharaan. Jakarta: Erlangga.

[2] Partner, Mgruppen. Industrial Maintenance Management. Sweden: Nykoping.

[3] Smith, Anthony, M,. Hill, Mc, Graw. 1993. Reliability Centered Maintenance.

[4] Nakajima, Seiichi. 1989 Implementing Total Productive Maintenance. Tokyo: Japan Institute for Plant Maintenance.

[5] Ebeling, Charles, E,. Hill, Mc, Graw. 1997. Introduction To Reliability and Maintability Engineering.

[6] Sudrajat, Ating. 2011. Manajemen Perawatan Mesin Industri. Bandung: Reflika Aditama.

[7] Turban, Efraim., McClesn, Ephraim., Wetherbe, James. 1999. Information Technology for Management Making Connections for Strategis Advance (2nd ed.). John Wiley \& Sons,Inc.

[8] Ramachandra, C.G, Srinivas, T.R., Shruthi, T.S. 2012. A Study on Development and Implementation of a Computerized Maintenance Management Information System for a Process Industry. International Journal of Engineering and Innovative Technology (IJEIT) Volume 2, Issue 5

\section{BIODATA PENULIS}

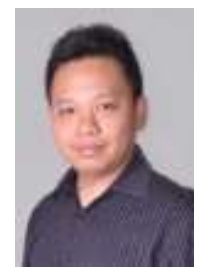

Arief Samuel Gunawan S.T., MIM., menerima gelar Sarjana Teknik dari Universitas Katolik Parahyangan Bandung Jurusan Teknik Industri pada Tahun 2003, dan gelar Master in Industrial Management dari Katholieke Universiteit Leuven, Belgia pada tahun 2004. Saat ini menjabat sebagai dosen di Institut Teknologi Harapan Bangsa di Program Studi Manajemen Rantai Pasok dan Sistem Informasi. Area penelitian di bidang Enterprise Resource Planning (ERP) dan Supply Chain Management.

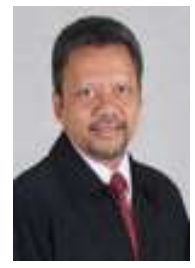

Ari Setiawan M.T., menerima gelar Sarjana Teknik dari Jurusan Teknik Mesin Institut Teknologi Bandung pada tahun 1989 dan gelar Magister Teknik Industri dari Institut Teknologi Bandung pada tahun 1997. Saat ini sedang melanjutkan studi Doktoral Teknik Industri di Institut Teknologi Bandung dan menjabat sebagai Kepala Program Studi Teknik Industri di Institut Teknologi Harapan Bangsa. Area penelitian di bidang FMS, Penjadwalan Produksi, Maintenance, Machine Tools dan Proses Manufaktur.

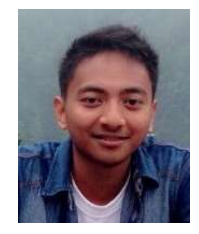

Febryci Legirian adalah adalah alumni Sistem Informasi ITHB angkatan 2011. Konsentrasi studi dan peminatan pada Sistem Enterprise, Manajemen Operasional dan Logistik, serta EBusiness. 